\title{
Prevalence and risk factors for mortality related to COVID-19 in a severely affected area of Madrid, Spain
}

Authors: Ramón Pérez-Tanoira ${ }^{1, ¥, *}$, Felipe Pérez-García ${ }^{1, ¥}$, Juan Romanyk ${ }^{1,2}$, Peña Gómez-Herruz ${ }^{1}$, Teresa Arroyo ${ }^{1}$, Rosa González ${ }^{1}$, Lourdes Lledó García ${ }^{2}$, Cristina Verdú Expósito ${ }^{2}$, José Sanz Moreno ${ }^{3}$, Isabel Gutiérrez

${ }^{4}$, Abel Uribe Mathews ${ }^{5}$, Esther López Ramos ${ }^{6}$, Lara Maceda Garcia ${ }^{7}$, Daniel Troncoso ${ }^{8}$, Juan Cuadros-González 1,2

(*), Correspondence: ramontanoira@hotmail.com

(¥), Both authors contributed equally to this study.

\section{Authors affiliations:}

(1), Departamento de Microbiología Clínica, Hospital Universitario Príncipe de Asturias, Madrid, Spain.

(2), Departamento de Biomedicina y Biotecnología, Facultad de Medicina, Universidad de Alcalá de Henares, Spain.

(3), Departamento de Medicina Interna, Hospital Universitario Príncipe de Asturias, Madrid, Spain.

(4), Departamento de Hematología, Hospital Universitario Príncipe de Asturias, Madrid, Spain.

(5), Departamento de Urgencias, Hospital Universitario Príncipe de Asturias, Madrid, Spain.

(6), Unidad de cuidados intensivos, Hospital Universitario Príncipe de Asturias, Madrid, Spain.

(7), Departamento de Bioquímica, Hospital Universitario Príncipe de Asturias, Madrid, Spain.

(8), Departamento de Medicina Preventiva, Hospital Universitario Príncipe de Asturias, Madrid, Spain.

Correspondence author: Ramón Pérez-Tanoira; Hospital Universitario Príncipe de Asturias. Servicio de Microbiología Clínica. Carretera de Alcalá, s/n, 28805 Meco (Madrid); Telf.: + 34918781 00; e-mail: ramontanoira@hotmail.com

\section{Abstract}


BACKGROUND: The coronavius disease 2019 (COVID-19) caused by the severe acute respiratory syndrome coronavirus 2 (SARS-CoV-2) reached Spain by 31 January 2020, in April 2020, the Comunidad de Madrid suffered one of the world's highest crude mortality rate ratios. This study aimed to detect risk factors for mortality in patients with COVID-19.

METHODS: Our cohort were all consecutive adult patients ( $\geq 18$ years) with laboratory-confirmed COVID-19 at a secondary hospital in Madrid, March 3-16, 2020. Clinical and laboratory data came from electronic clinical records and were compared between survivors and non-survivors, with outcomes followed up until April 4. Univariable and multivariable logistic regression methods allowed us to explore risk factors associated with in-hospital death.

FINDINGS: The cohort comprised 562 patients with COVID-19. Clinical records were available for evaluation for 392 patients attended at the emergency department of our hospital, of whom 199 were discharged, 85 remained hospitalized and 108 died during hospitalization. Among 311 of the hospitalized patients, $34.7 \%$ died. Of the 392 patients with records, the median age was 71.5 years (50.6-80.7); 52.6\% were men. 252 (64.3\%) patients had a comorbidity, hypertension being the most common: 175 (44.6\%), followed by other cardiovascular disease: 102 (26.0\%) and diabetes: 97 (24.7\%). Multivariable regression showed increasing odds of in-hospital death associated with age over 65 (odds ratio 8.32, 95\% CI 3.01-22.96; $\mathrm{p}<0.001$ ), coronary heart disease $(2.76,1.44-5.30 ; 0.002)$, and both lower lymphocyte count $(0.34,0.17-0.68 ; 0.002)$ and higher LDH $(1.25,1.05-1.50 ; 0.012)$ per 1-unit increase and per 100 units respectively.

INTERPRETATION: COVID-19 was associated in our hospital at the peak of the pandemic with a crude mortality ratio of $19.2 \%$ and a mortality ratio of $34.7 \%$ in admitted patients, considerably above most of the ratios described in the Chinese series. These results leave open the question as to which factors, epidemiological or intrinsically viral, apart from age and comorbidities, can explain this difference in excess mortality.

FUNDING: None.

\section{INTRODUCTION}

In December, 2019, after a series of pneumonia cases emerged in Wuhan, Hubei, China (1), sequencing analysis of samples from the lower respiratory tract indicated a coronavirus: new coronavirus 2019 (2019-nCoV) $(2,3)$. The WHO determined that this situation should be considered a public health emergency of international interest on January 30, 2020 (2). The COVID pandemic has shattered the foundations of our healthcare system in the Comunidad de Madrid, Spain, with a total of 62817 cases and 13409 deaths as of May 1, 2020, and one of the highest crude mortality rate ratios worldwide (20\%) (4). The Spanish government declared a state of national emergency, starting on March 15 (5).

At the beginning of the pandemic, almost all the resources of our hospital were allocated to fight this disease. By March 5, Spain had reported only 261 cases and 3 deaths (6), and the first diagnoses were confirmed in our laboratory. The initial prevalence in patients who attended our emergency department was $26 \%$, which progressively increased to values of $35-40 \%$ in a few days, which indicated a clear pattern of community transmission. and a widespread dissemination of the virus at that time. By March 23, 1646 cases had been confirmed, and 566 patients were admitted to our hospital with a diagnosis of COVID by PCR or unaffiliated pneumonia with a clinical diagnosis of COVID. As this is the only reference hospital in this area, we have reviewed all those confirmed by PCR diagnosis in the initial period ( 3 to 16 March) to determine the clinical impact of the epidemic in this period of maximal incidence, just before and shortly after the population was confined in their homes. 
Here, we present details of all patients admitted to the Hospital Universitario Príncipe de Asturias (Alcalá de Henares, Madrid, Spain) with laboratory-confirmed COVID-19 and a definite clinical outcome (death or discharge) as of April 4,2020. We aim to assess mortality rates and morbidity of all patients admitted to our center at the beginning of the COVID-19 epidemic and investigate the risk factors associated with an increase in mortality.

\section{MATERIAL AND METHODS}

\section{Settings and study design}

We conducted the study in a middle-sized center with 453 beds and a catchment population of approximately 243 000 inhabitants in Madrid, Spain. This was a retrospective study on confirmed adult cases of COVID-19, March 3 16. A confirmed case of COVID-19 was defined as a patient with at least one compatible clinical symptom (fever > $37.5 \square \mathrm{C}$, cough, or dyspnea) and a positive RT-PCR result for SARS-CoV-2 in a nasopharyngeal specimen or lower respiratory tract samples (sputum or bronchial aspirate) (7-9).

\section{Diagnostic procedures}

The diagnosis of SARS-CoV-2 infection was performed in our centre according to the protocol established by the WHO (10). Briefly, by two automatic extractors we obtained viral RNA from clinical samples: MagCore HF16 (RBC Bioscience, Taipei, Taiwan) and Hamilton Microlab Starlet (Hamilton Company, Bonaduz, Switzerland). RNA amplification was done with two real-time PCR platforms: VIASURE SARS-CoV-2 Real Time PCR Detection Kit (Certest Biotech, Zaragoza, Spain) and Allplex 2019-nCoV assay (Seegene, Seoul, South Korea), all used according to manufacturer's instructions.

\section{Inclusion and exclusion criteria}

For incidence and mortality analysis, all consecutive patients with a confirmed diagnosis by RT-PCR in nasopharyngeal-, sputum-. or lower-tract respiratory samples were included, and for the risk factors analysis, all adult patients attending the emergency department of our hospital.

Clinical data from electronic clinical records included age, sex, comorbidities (hypertension, diabetes mellitus, coronary heart disease, chronic obstructive pulmonary disease (COPD), chronic kidney disease, immunosuppression), symptoms (fever, cough, dyspnea), days from illness onset to hospital admission, laboratory data (lymphocyte count, aspartate aminotransferase (AST), alanine aminotransferase (ALT), lactate dehydrogenase, D-dimer, ferritin, and interleukin-6 (IL-6).

Treatments included any of these drugs or their combinations: a) antiretroviral treatment (darunavir/cobicistat or ritonavir/lopinavir), b) chloroquine or hydroxychloroquine, c) tocilizumab or d) type 1 interferon.

\section{Study definitions and outcome description}

Severity of infection was classified according to WHO criteria. Briefly, patient infections were classified as: a) mild disease (patients with uncomplicated disease perhaps including non-specific symptoms) b) pneumonia (adult with pneumonia but no signs of severe pneumonia and no need for supplemental oxygen), c) severe pneumonia (fever or suspected respiratory infection, plus one of the following: respiratory rate $>30$ breaths/min; severe respiratory distress or $\mathrm{SpO} 2 \leq 93 \%$ on room air), d) acute respiratory distress syndrome (within 1 week of a known clinical insult or new or worsening respiratory symptoms), e) sepsis ( life-threatening organ dysfunction caused by a dysregulated host response to suspected or proven infection) and f) septic shock (persistent hypotension despite volume resuscitation, requiring vasopressors to maintain $\mathrm{MAP} \geq 65 \mathrm{mmHg}$ and serum lactate level $>2 \mathrm{mmol} / \mathrm{L}$.) (11).

Immunosuppression at the time of presentation was considered to be present when at least one of the following conditions were documented: administration of corticosteroids (prednisone [10 $\mathrm{mg}]$ or equivalent) or other immunosuppressive drug within the last month, and receipt of active antineoplastic treatment. Criteria for 
discharging patients in this hospital were normal body temperature for three days, two negative PCR results at 24-h intervals, and resolution of all clinical symptoms.

\author{
Statistical analysis \\ Continuous variables were presented as median and interquartile range (IQR) and categorical variables as \\ proportions. We used the Mann-Whitney U-test, $\chi 2$ test, or Fisher's exact test to compare differences between \\ survivors and non-survivors where appropriate. For these comparisons, a $p$ value of 0.05 or below was considered \\ significant. Statistical analysis was performed with SPSS v20.0 (IBM Corp., Armonk, NY, USA).
}

Univariable and multivariable logistic regression models served to analyze risk factors associated with in-hospital death. The logistic regression model was adjusted by the most significant variables, with results expressed as odds ratio (OR) and 95\% confidence intervals (95\% CI). Considering the 392 patients attending the emergency department and to avoid overfitting in the model, nine variables were chosen for multivariable analysis on the basis of previous findings and clinical constraints.

Finally, in order to estimate the prevalence of SARS-CoV-2 infection both in the municipality Alcala de Henares and in Spain, we assessed the age distribution of all patients with COVID-19 by discharge status. We adjusted the age profile of Spanish patients by the population of the municipality Alcala de Henares and of Spain. We used 2019 population estimates from the Statistics National Institute (https://www.ine.es) to calculate the relative risk (RR) of infection with COVID-19 by age group. To calculate the RR, we followed the method of Lemaitre and colleagues (12) to explore the age profile of influenza, where RR for age group is defined as

$\mathrm{RRi}=\left(\mathrm{Ci} / \sum \mathrm{i} \mathrm{Ci}\right) /\left(\mathrm{Ni} / \sum \mathrm{i} \mathrm{Ni}\right)$

where $\mathrm{Ci}$ is the number of cases in age group $\mathrm{i}$, and $\mathrm{Ni}$ is the population size of age-group $\mathrm{i}$.

\title{
Results
}

A total of 562 adult patients were diagnosed with SARS-CoV-2 infection in our hospital in the period of study (3-16 March, 2020), and of those, 108 died: a crude mortality rate of 19\%. The mortality rate in patients attending the emergency department was $27 \%$ and for those admitted to the hospital was $34 \%$. Considering that this hospital serves an area of 249578 inhabitants, we determined an accumulated incidence of the disease of 225/100 000 and an accumulated mortality of 43/100 00 inhabitants.

For the risk factor analysis, all 392 patients attending the emergency department were included, but 170 other patients attending the department of occupational health or in primary care were excluded, due to a lack of key information in their medical records. Demographic and clinical findings are summarized in table 1. Briefly, their median age was 71.5 years (IQR:50.6-80.7), ranging from 23 to 99, and approximately half were male (52.6\%); 311 were hospitalized, and 81 were discharged from the emergency department. Comorbidities were present in most patients, with hypertension being the most common (44.6\%), followed by cardiovascular disease $(26.0 \%)$ and diabetes $(24.7 \%)$. These patients showed the following clinical syndromes: 106 mild disease $(27.0 \%), 141$ pneumonia (36.0\%), 116 severe pneumonia (29.6\%), 27 ARDS (6.9\%), and one each with sepsis and septic shock $(0.3 \%)$. Of the $392,108(27.6 \%)$ died during hospitalization, and most patients were male (table 1$)$.

\section{Table 1· Demographic and clinical findings of patients on admission}


medRxiv preprint doi: https://doi.org/10.1101/2020.05.25.20112912; this version posted May 26, 2020. The copyright holder for this preprint (which was not certified by peer review) is the author/funder, who has granted medRxiv a license to display the preprint in perpetuity. All rights reserved. No reuse allowed without permission.

Total $(\%)$

392

$71(51-81)$

(IQR)

$\geq 65$ years $(\%)$

Sex (male) (\%)

Comorbidities (\%)

Hypertension

(\%)

Diabetes (\%)

Cardiovascular

disease (\%)

COPD (\%)
$175(44 \cdot 6)$

97 (24.7)

$102(26 \cdot 0)$

$240(61 \cdot 2)$

$206(52 \cdot 6)$

$252(64 \cdot 3)$

$58(14 \cdot 8)$
Exitus (\%)

$108(27 \cdot 6)$

$83(75-87)$

$101(93 \cdot 5)$

$63(58 \cdot 3)$

$96(88.9)$

$71(65 \cdot 7)$

$40(37 \cdot 0)$

$55(50 \cdot 9)$

$27(25 \cdot 0)$
$104(36 \cdot 6)$

$156(54.9)$

$<0 \cdot 001$

Alive (\%)

$64(48-75)$

$139(48.9)$

$<0 \cdot 001$

$143(50 \cdot 4)$

$0 \cdot 157$

57(20·1)

$\leq 0 \cdot 001$

47 (16.5)

$<0 \cdot 001$

$31(10 \cdot 9)$ p value

$<0 \cdot 001$ 
medRxiv preprint doi: https://doi.org/10.1101/2020.05.25.20112912; this version posted May 26, 2020. The copyright holder for this preprint (which was not certified by peer review) is the author/funder, who has granted medRxiv a license to display the preprint in perpetuity. All rights reserved. No reuse allowed without permission.

\begin{tabular}{|c|c|c|c|c|}
\hline Carcinoma (\%) & $53(13 \cdot 5)$ & $24(22 \cdot 2)$ & $29(10 \cdot 2)$ & $0 \cdot 003$ \\
\hline $\begin{array}{l}\text { Chronic kidney } \\
\text { disease (\%) }\end{array}$ & $38(9.7)$ & $17(15 \cdot 7)$ & $21(7 \cdot 4)$ & $0 \cdot 015$ \\
\hline $\begin{array}{l}\text { Immunosuppres } \\
\text { sion }(\%)\end{array}$ & $29(7.4)$ & $14(13 \cdot 0)$ & $15(5 \cdot 3)$ & $0 \cdot 011$ \\
\hline $\begin{array}{l}\text { Fever on admission } \\
\left(\text { temperature } \geq 37 \cdot 5^{\circ} \mathrm{C}\right) \\
(\%)\end{array}$ & $268(68 \cdot 4)$ & $70(64 \cdot 8)$ & $198(69 \cdot 7)$ & $0 \cdot 220$ \\
\hline $\begin{array}{l}\text { Cough on admission } \\
(\%)\end{array}$ & $249(63 \cdot 5)$ & $69(63.9)$ & $180(63 \cdot 4)$ & $0 \cdot 874$ \\
\hline $\begin{array}{l}\text { Pneumonia on } \\
\text { admission (\%) }\end{array}$ & $281(71 \cdot 7)$ & $97(89.8)$ & $184(64 \cdot 8)$ & $<0.001$ \\
\hline $\begin{array}{l}\text { Disnea on admission } \\
\text { (\%) }\end{array}$ & $212(54 \cdot 1)$ & $87(80 \cdot 6)$ & $125(44 \cdot 0)$ & $<0.001$ \\
\hline Disease severity status &.. & .. & .. & $<0.001 *$ \\
\hline $\begin{array}{l}\text { Mild disease or } \\
\text { non-severe } \\
\text { pneumonia }(\%)\end{array}$ & $106(27 \cdot 0)$ & $6(5 \cdot 6)$ & $100(33 \cdot 4)$ & \\
\hline
\end{tabular}


medRxiv preprint doi: https://doi.org/10.1101/2020.05.25.20112912; this version posted May 26, 2020. The copyright holder for this preprint (which was not certified by peer review) is the author/funder, who has granted medRxiv a license to display the preprint in perpetuity. All rights reserved. No reuse allowed without permission.

\begin{tabular}{|c|c|c|c|c|}
\hline $\begin{array}{l}\text { Severe } \\
\text { pneumonia (\%) }\end{array}$ & $141(36 \cdot 0)$ & $18(16 \cdot 7)$ & $123(43 \cdot 0)$ & \\
\hline Critical (\%) & $145(37 \cdot 0)$ & $84(77 \cdot 8)$ & $61(21 \cdot 5)$ & \\
\hline $\begin{array}{l}\text { Illness onset to hospital } \\
\text { admission, days }\end{array}$ & $3(7-2)$ & $3(5-2)$ & $4(7-2)$ & $0 \cdot 024$ \\
\hline \multicolumn{5}{|l|}{ Laboratory findings } \\
\hline $\begin{array}{l}\text { Lymphocyte } \\
\text { count } * 10^{3}, / \mu L(n=352)\end{array}$ & $0.89(0.66-1.26)$ & $0.70(0.49-1.00)$ & $0.97(0.72-1.34)$ & $<0 \cdot 001$ \\
\hline AST, U/L (n=212) & $34 \cdot 0(25 \cdot 0-50 \cdot 8)$ & $34 \cdot 0(25 \cdot 2-55)$ & $34 \cdot 0(25 \cdot 0-49 \cdot 0)$ & $0 \cdot 867$ \\
\hline ALT, U/L (n=287) & $26 \cdot 0(18 \cdot 0-42 \cdot 0)$ & $22 \cdot 5(14 \cdot 0-36 \cdot 5)$ & $27 \cdot 0(19 \cdot 0-43 \cdot 0)$ & $0 \cdot 007$ \\
\hline LDH, U/L (n=306) & $293(228 \cdot 5-380 \cdot 2)$ & $302.5(240.5-431 \cdot 0)$ & $288 \cdot 0(215 \cdot 0-341 \cdot 5)$ & $0 \cdot 008$ \\
\hline Ferritin $(\mathrm{ng} / \mathrm{mL})(\mathrm{n}=\mathbf{7 3})$ & $520 \cdot 0(235 \cdot 5-947 \cdot 0)$ & $654 \cdot 5(293 \cdot 8-1711 \cdot 8)$ & $496 \cdot 0(219 \cdot 0-809 \cdot 0)$ & $0 \cdot 127$ \\
\hline D-dimer $(\mu \mathrm{g} / \mathrm{L})(\mathrm{n}=97)$ & $1 \cdot 1(0 \cdot 5-1 \cdot 9)$ & $1 \cdot 4(1 \cdot 0-2 \cdot 2)$ & $1.0(0.4-1.7)$ & $\mathbf{0 \cdot 0 2 2}$ \\
\hline
\end{tabular}


medRxiv preprint doi: https://doi.org/10.1101/2020.05.25.20112912; this version posted May 26, 2020. The copyright holder for this preprint (which was not certified by peer review) is the author/funder, who has granted medRxiv a license to display the preprint in perpetuity.

All rights reserved. No reuse allowed without permission.

Statistics: values are expressed as median (IQR) and absolute count (percentage). $P$-values calculated by Mann-Whitney $U$ test, $X 2$ test, or Fisher's exact test, as appropriate. Significant differences in bold. * $x^{2}$ test comparing all subcategories. Abbreviations: IQR interquartile range, AST, aspartate aminotransferase; ALT alanine aminotransferase; COPD, chronic obstructive pulmonary disease; LDH, lactate dehydrogenase

A total of 185 (48.4\%) patients received antibiotics, 187 (49.0\%) antiviral drugs (lopinavir/ritonavir or darunavir / cobicistat), and $181(47.4 \%)$ chloroquine/hydroxychloroquine, tocilizumab, or type 1 interferon. No significant differences emerged related to the use of these drugs between non-survivors and survivors (table 2).

Table 2· Treatments and outcomes

Treatments*

\begin{tabular}{l|l|l|l|}
$\begin{array}{l}\text { Total } \\
(\mathbf{n}=382)\end{array}$ & $\begin{array}{l}\text { Non-survivor } \\
(\mathbf{n = 1 0 5})\end{array}$ & $\begin{array}{l}\text { Survivor } \\
(\mathbf{n}=\mathbf{2 7 7})\end{array}$ & p-value \\
\hline
\end{tabular}

$185(48 \cdot 4)$

$67(63 \cdot 8)$

$118(42 \cdot 6)$

$<0 \cdot 001$

Chloroquine/ Hydroxychloroquine

$167(43 \cdot 7)$

$41(39 \cdot 0)$

$126(45 \cdot 5)$

$0 \cdot 257$

(\%)

Antiretroviral treatment (\%)

187 (49.0)

45 (42.9)

$142(51 \cdot 3)$

$0 \cdot 142$

Tocilizumab (\%)

$36(9.4)$

$10(9.5)$

$26(9 \cdot 4)$

0.967

Type 1 interferon (\%)

$64(16 \cdot 8)$

$24(22 \cdot 9)$

$40(14 \cdot 4)$

0.049 
medRxiv preprint doi: https://doi.org/10.1101/2020.05.25.20112912; this version posted May 26, 2020. The copyright holder for this preprint

(which was not certified by peer review) is the author/funder, who has granted medRxiv a license to display the preprint in perpetuity.

All rights reserved. No reuse allowed without permission.

Outcomes

ICU (\%)

$34(8 \cdot 7)$

$13(12 \cdot 0)$

21(7.4)

$0 \cdot 177$

Hospitalization, days, median

$5(1-10)$

$6(2-10)$

$4(0-10)$

$0 \cdot 012$

(IQR)

Antiretroviral treatment (darunavir/cobicistat or ritonavir/lopinavir). Data are median (IQR) or $n$ (\%). p values calculated by Mann-Whitney U test, $\chi 2$ test, or Fisher's exact test, as appropriate. Abbreviations: IQR interquartile range ICU=intensive care unit.

In univariable analysis, odds of in-hospital death were higher in patients with any comorbidity (table 3). Age, lymphopenia, and elevated lactate dehydrogenase were also associated with death (table 3). Multivariable regression showed increasing odds of in-hospital death associated with age over 65 (odds ratio 8.32, 95\% CI 3.01-22.96; $\mathrm{p}<0.001)$, coronary heart disease $(2.76,1.44-5.30 ; 0.002)$, and both lower lymphocyte count $(0.34,0.17-0.68 ; 0.002)$ and higher LDH $(1.25,1.05-1.50 ; 0.012)$ per 1 -unit increase and per 100 units respectively (table 3$)$.

\section{Table 3. Risk factors associated with in-hospital death}

\begin{tabular}{|l|l|l|l|}
\hline Univariate & p value & Multivariate & p value \\
OR $(95 \%$ & & OR & \\
\hline CI) & & $(95 \%$ CI $)$ & \\
\hline
\end{tabular}

Demographics and clinical characteristics

Age, years*

$1 \cdot 12(1 \cdot 09-1 \cdot 14) \quad<0 \cdot 001$

Sex, male vs. female

$1 \cdot 38(0 \cdot 88-2 \cdot 16)$

$0 \cdot 158$

>65years

$\begin{array}{ll}15.05 & <0.001\end{array}$

$8 \cdot 32(3 \cdot 01-22 \cdot 96)$

$<0.001$

$(6 \cdot 76-33 \cdot 52)$ 
medRxiv preprint doi: https://doi.org/10.1101/2020.05.25.20112912; this version posted May 26, 2020. The copyright holder for this preprint (which was not certified by peer review) is the author/funder, who has granted medRxiv a license to display the preprint in perpetuity.

All rights reserved. No reuse allowed without permission.

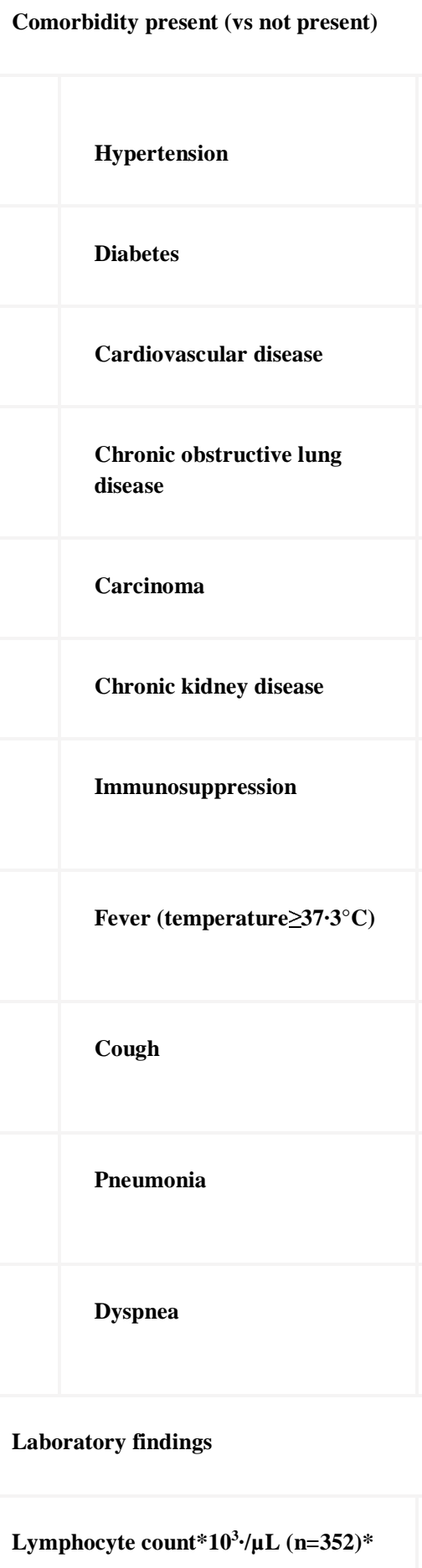

\begin{tabular}{|c|c|c|c|c|}
\hline Hypertension & $3 \cdot 21(2 \cdot 02-5 \cdot 12)$ & $<0.001$ & $1 \cdot 20(0 \cdot 61-2 \cdot 36)$ & 0.595 \\
\hline Diabetes & $2 \cdot 28(1 \cdot 40-3 \cdot 71)$ & $<0.001$ & $1.31(0.67-2.56)$ & 0.425 \\
\hline Cardiovascular disease & $5 \cdot 10(3 \cdot 12-8 \cdot 33)$ & $<0.001$ & $2 \cdot 76(1 \cdot 44-5 \cdot 30)$ & 0.002 \\
\hline $\begin{array}{l}\text { Chronic obstructive lung } \\
\text { disease }\end{array}$ & $1.33(1.01-1.76)$ & $0 \cdot 042$ & $1.12(0.76-1.64)$ & 0.578 \\
\hline Carcinoma & $2 \cdot 45(1 \cdot 35-4 \cdot 45)$ & 0.003 & $1.59(0.70-3.62)$ & 0.270 \\
\hline Chronic kidney disease & $2 \cdot 29(1 \cdot 16-4 \cdot 52)$ & $0 \cdot 018$ & $1.34(0.56-3.18)$ & 0.512 \\
\hline Immunosuppression & $2 \cdot 61(1 \cdot 21-5 \cdot 61)$ & $0 \cdot 011$ & $1.61(0.534-4.86)$ & 0.397 \\
\hline Fever (temperature $\geq 37 \cdot 3^{\circ} \mathrm{C}$ ) & $0.74(0 \cdot 46-1 \cdot 19)$ & $0 \cdot 220$ & & \\
\hline Cough & $0.96(0 \cdot 61-1 \cdot 53)$ & $0 \cdot 874$ & & \\
\hline Pneumonia & $4 \cdot 51(2 \cdot 30-8 \cdot 82)$ & $<0.0001$ & & \\
\hline Dyspnea & $5.07(2.98-8.63)$ & $<0 \cdot 0001$ & & \\
\hline
\end{tabular}

\begin{tabular}{l} 
Comorbidity present (vs not present) \\
Hypertension \\
Diabetes \\
\hline Cardiovascular disease \\
\hline Chronic obstructive lung \\
disease \\
\hline Carcinoma \\
\hline Pneumonia \\
\hline Fever (temperature $\geq 37 \cdot \mathbf{3}^{\circ} \mathbf{C}$ ) \\
\hline Chronic kidney disease \\
\hline
\end{tabular} 
medRxiv preprint doi: https://doi.org/10.1101/2020.05.25.20112912; this version posted May 26, 2020. The copyright holder for this preprint (which was not certified by peer review) is the author/funder, who has granted medRxiv a license to display the preprint in perpetuity.

All rights reserved. No reuse allowed without permission.

$\mathbf{L D H} \cdot \mathbf{U} / \mathbf{L}(\mathbf{n}=\mathbf{3 0 6})^{* * *}$

Ferritin $(\mathbf{n g} / \mathbf{m L})(\mathbf{n}=73) *$

D-dimer $(\mu \mathrm{g} / \mathbf{L})(\mathrm{n}=97)^{*}$
$1 \cdot 29(1 \cdot 11-1 \cdot 50)$

$1 \cdot 00(1 \cdot 00-1 \cdot 00)$

$1 \cdot 01(0 \cdot 85-1 \cdot 20)$ $\leq 0 \cdot 001$

$1.25(1.05->1.49)$

$0 \cdot 012$

$\mathrm{OR}=$ odds ratio. $\mathrm{ALT}=$ alanine aminotransferase. $\mathrm{AST}=$ Aspartate transaminase. *Per one unit increase. $* *$ per 100 units increase

Adjustment for the age demographics of Spain confirmed a deficit of infections among children, with a RR below 0.5 in patients younger than 24 years (figure 1). The RR measure indicated a sharp increase in the likelihood of reported COVID-19 among those aged 70 years and older, and the same for mortality.

Figure 1. Age distribution of patients with COVID-19 from crowdsourced data (A) All 562 cases by disease outcome (alive or unknown or deceased at time of reporting); vertical bars are case counts in each age group, and dotted lines show the median age for patients who were alive or with unknown outcomes at the time of reporting and those who had died by the time of reporting. (B) Relative risk in both Spain and the municipality Alcalá de henares by 5-year age band for 562 cases reported in the Hospital Universitario Príncipe de Asturias. The data case-count quantities are bars and estimated relative risk by spline-smoothed curve. COVID-19=coronavirus disease 2019.

a)

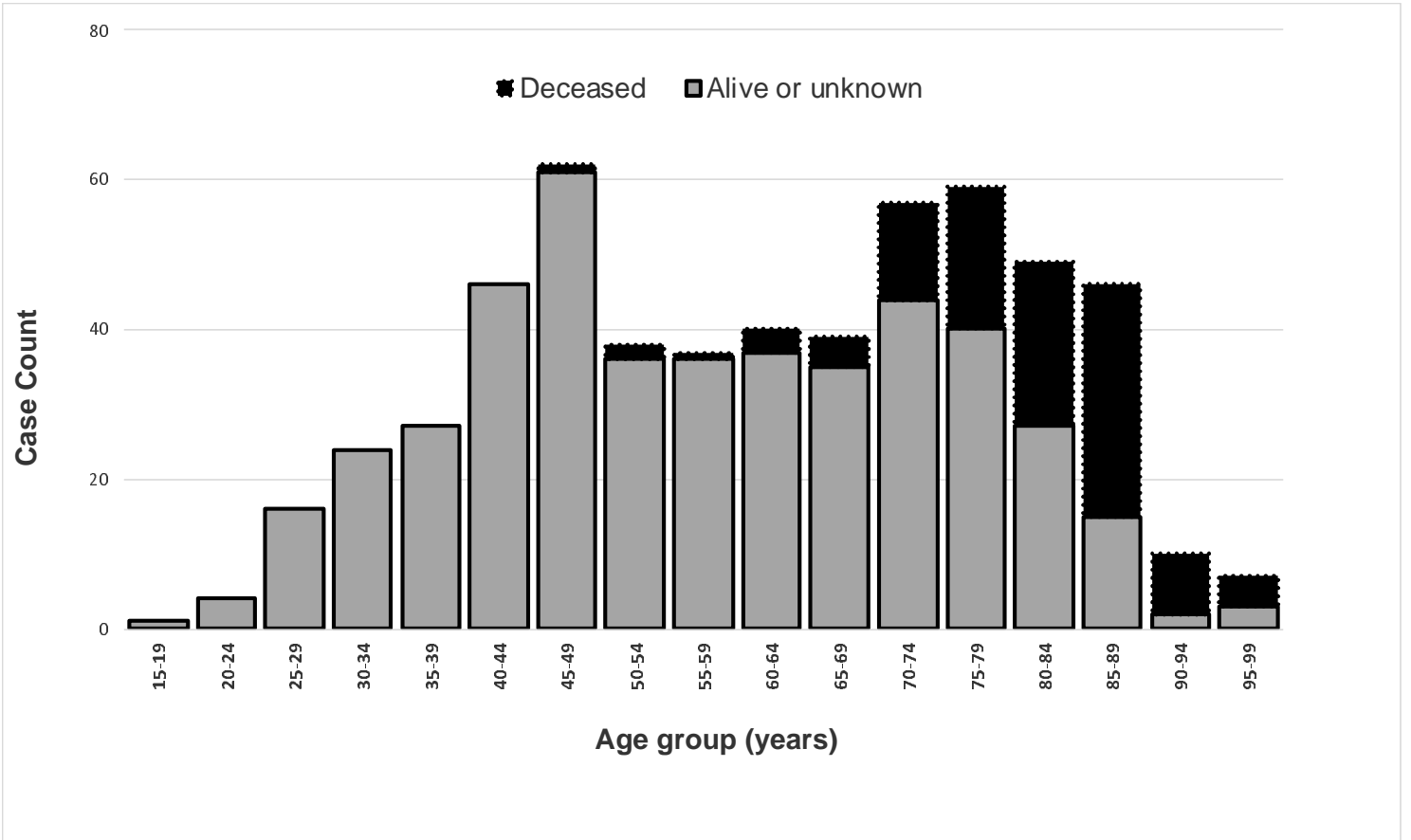

b) 


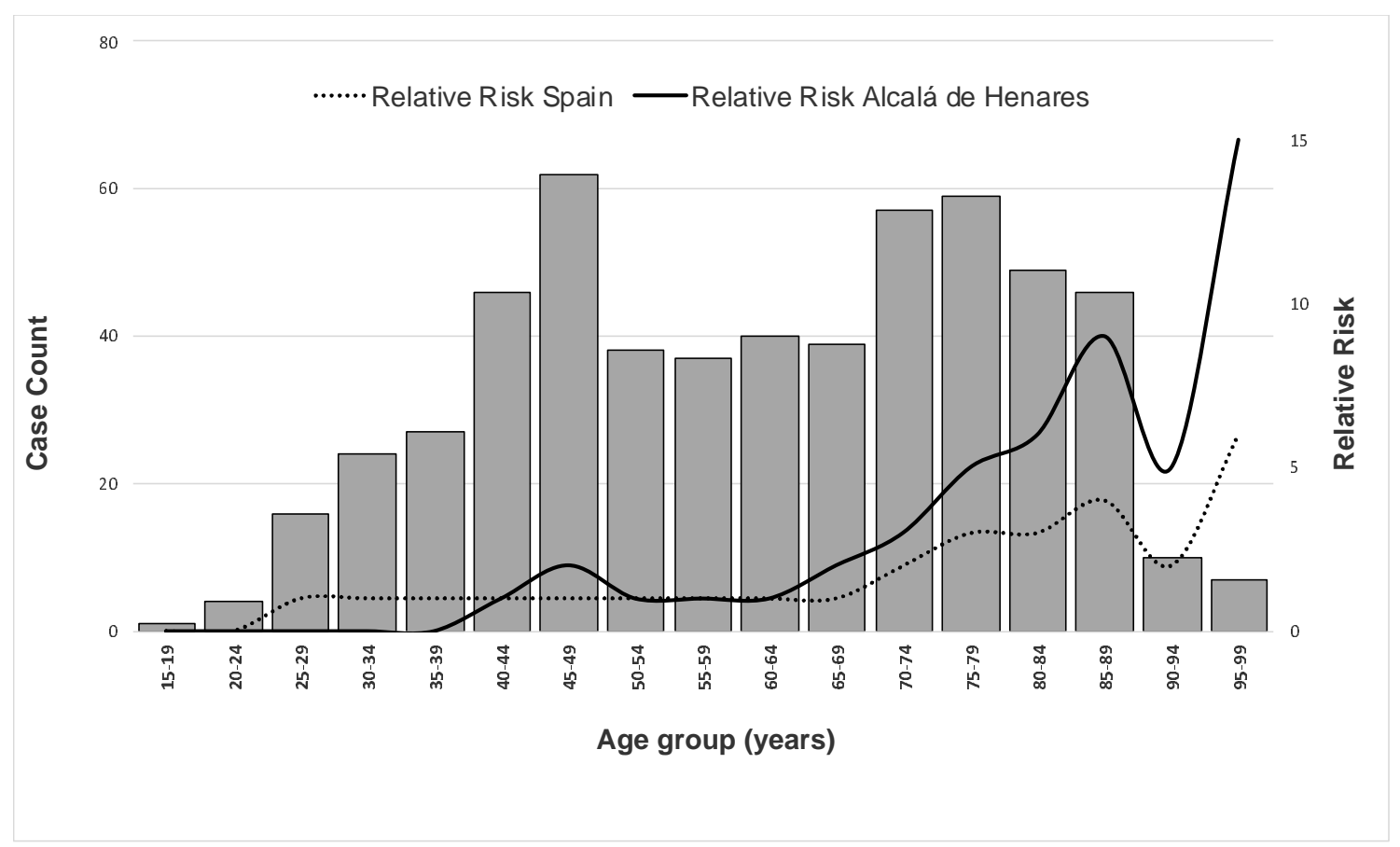

\section{Discussion}

The majority of published studies regarding risk factors, severity of the disease and mortality in patients with COVID-19 come from China. The study designs range from retrospective studies, single center (13) and multicenter $(8,14,15)$, to prospective studies (16) and meta-analysis (17). All of them mention advanced age (over aged 65) and comorbidities (especially hypertension) as factors predicting poor prognosis and mortality. Other factors mentioned are heart disease (14), diabetes (9), high lactate dehydrogenase (LDH) levels, lymphopenia or elevation of d-dimer $(15,18)$ as well as male sex (7) or high sequential organ failure assessment score (SOFA) (14).

Few studies focus on these aspects in countries of the European Union affected by this pandemic such as Italy (19), or the United Kingdom (20), due to the short time elapsed since the start of the epidemic in Europe. In a recent multicenter study (1), the authors underline the priority of monitoring transmissibility and mortality in countries like France and Spain.

In this study, univariate analysis shows a clear statistically significative association between death and most of these risk factors: age, hypertension, diabetes, coronary heart disease, COPD, pneumonia, dyspnea, LDH levels, and lymphopenia. Multivariate logistic regression analysis reveals advanced age as a strong predictor for death from COVID-19, consistent with the findings of Du and colleagues (16). In our cohort, SARS-CoV-2 induced a community-acquired lymphopenic pneumonia characterized by lymphopenia, supporting earlier findings (21), and the existence of immunological dysregulation as an accompanying event of this critical illness.

The $27 \%$ mortality rate in patients coming through our emergency department is comparable to that of Zhou and colleagues in their reports, and is much higher than published rates in China of $11 \%$ (8) and 6\% (22). This difference may depend on these series being at the beginning of their pandemic (January to February), when the disease was still poorly developed. On the other hand, $64 \%$ of our patient cohort presented with comorbidities in comparison to $51 \%$ in the cohort of Huang and colleagues which showed 15\% mortality and 32\% comorbidities (23).

From age 70, the relative risk of acquiring coronaviruses in our area was double that found with the same analysis but taking into account the age-structure of the Spanish general population. Our close association between advanced age and mortality rates, especially in the 70-90 age group, can be explained by our median age of 71.5, in contrast with the Chinese series with medians as low as 47 (9), 49 (24) or 56 (22). 
Of our 392 patients, 85 (21.7\%) were discharged and 311 (79.3\%) were eventually hospitalized. The clinical spectrum in this cohort ranged from mild (27.0\%) to moderate $(36.0 \%)$ or severe (37.0\%) infection. Nearly all admitted patients with moderate or severe infection had chest-X-ray abnormalities: of 286, 281 (98.2\%), as such an abnormality was an admission criterion. No radiographic abnormalities were detectable in those with mild disease. Radiographic abnormalities are a constant in all published series of Covid-19 disease with rates ranging from $82 \%$ to $100 \%$ depending on degree of infection severity $(15,23,25)$.

We had 185 patients (48.4\%) treated with antibiotics. No differences appeared in relation to survival with any of the drugs administered to these COVID patients (lopinavir/ritonavir, chloroquine/hydroxichloroquine, tocilizumab, interferon $\beta-1 \mathrm{~B})$, which are being studied in currently ongoing trials $(23,24)$. In Spain, the health department through the AEMPS (the Spanish agency for medicines and health products) recommended a protocol for the treatment of the Covid-19, one which is available and permanently updated. However, this study was not designed for evaluation of drug efficacy, because dose and length of treatment were not registered; these results only provide background information as to the drugs used before the availability of any reliable evidence on their efficacy.

As Yang and collaborators observe, the severity of SARS-CoV-2 pneumonia places a great strain on critical care resources in hospitals, especially if their staff and resources do not match the number of patients that they must admit (26). Sometimes admission in ICUs had to be postponed or was impossible due to occupation of all the ICU beds; this can lead to deterioration of patients' lung status and prevent their weaning, thus extending their time in the ICU. In our hospital, during the time of the study, it was necessary to increase the number of beds that normally exist almost three times, from 14 to 39 beds. Finally, the shortage of doctors and nurses is a very critical issue. Extreme decisions have been necessary, such as relocating doctors and nurses or hiring doctors who have just graduated or who have not yet been licensed.

Our research may have some limitations. Firstly, due to the retrospective study design, not all laboratory tests were done in all patients, including lactate dehydrogenase, IL-6, serum ferritin, and d-dimer. Their role may therefore be underestimated in predicting in-hospital death. An additional limitation is that some patients were transferred to another hospital, so we could not follow their outcomes. Thirdly, the number of cases may be underestimated due to frequency of collection of respiratory samples and a relatively low positive rate of detection of SARS-CoV-2 RNA in throat swabs.

\section{Conclusions}

This study shows that the COVID epidemic had a huge impact in our community, with an accumulated incidence of the disease of 225/100 000 inhabitants and a mortality of 43/100 00 in the period 3-16 March, 2020. This difference in mortality rates in relation to previously reported series, mostly from China, leaves open the question of what other factors epidemiological or intrinsically viral, apart from age and comorbidities can explain this excess mortality. Early recognition of risk factors could be helpful in helping to quickly identify those severely affected.

\section{Acknowledgements}

We thank Carolyn Brimley Norris from the University of Helsinki Language Services for her aid in preparation of this manuscript.

\section{Funding}

This research received no specific grant from any funding agency in the public, commercial, or not-for-profit sectors.

\section{Compliance with Ethical Standards \\ Conflict of interest}

The authors declare that they have no conflicts of interest. 
medRxiv preprint doi: https://doi.org/10.1101/2020.05.25.20112912; this version posted May 26, 2020. The copyright holder for this preprint (which was not certified by peer review) is the author/funder, who has granted medRxiv a license to display the preprint in perpetuity.

All rights reserved. No reuse allowed without permission.

Since the present study is retrospective, informed consent was not required.

Ethical approval

The study was conducted according to the ethical requirements established by the Declaration of Helsinki. The Ethics Committee of Hospital Universitario Príncipe de Asturias (Madrid) approved the study.

\section{References}

(1) Yuan M, Yin W, Tao Z, Tan W, Hu Y. Association of radiologic findings with mortality of patients infected with 2019 novel coronavirus in Wuhan, China. PLoS One 2020 March 19;15(3):e0230548.

(2) WHO | Pneumonia of unknown cause - China. Available at: http://www.who.int/csr/don/05-january-2020pneumonia-of-unkown-cause-china/en/. Accessed Apr 13, 2020.

(3) Zhou F, Yu T, Du R, Fan G, Liu Y, Liu Z, et al. Clinical course and risk factors for mortality of adult inpatients with COVID-19 in Wuhan, China: a retrospective cohort study. The Lancet 2020;6736(20):1-9.

(4) 2019-Nuevo Coronavirus. 2020; Available at: https://www.comunidad.madrid/servicios/salud/2019-nuevocoronavirus. Accessed Apr 26, 2020.

(5) La Moncloa. 10/04/2020. Referencia del Consejo de Ministros [Consejo de Ministros/Referencias]. Available at: https://www.lamoncloa.gob.es/consejodeministros/referencias/Paginas/2020/refc20200410.aspx. Accessed Apr 26, 2020.

(6) Evolución del coronavirus en España: tres muertos y 261 confirmados. Available at:

https://www.redaccionmedica.com/secciones/neumologia/evolucion-coronavirus-covid-19-espana-jueves-5-marzo1710. Accessed Apr 26, 2020.

(7) World Bank Group. Available at: http://www.worldbank.org. Accessed Sep 27, 2016.

(8) Chen T, Wu D, Chen H, Yan W, Yang D, Chen G, et al. Clinical characteristics of 113 deceased patients with coronavirus disease 2019: retrospective study. BMJ 2020;368:m1091.

(9) Guan W, Ni Z, Hu Y, Liang W, Ou C, He J, et al. Clinical Characteristics of Coronavirus Disease 2019 in China. New England Journal of Medicine 2020 February 28;;0(0):null.

(10) Loeffelholz MJ, Tang Y. Laboratory diagnosis of emerging human coronavirus infections-the state of the art. Emerging microbes \& infections 2020(just-accepted):1-26.

(11) World HO. Clinical management of severe acute respiratory infection (SARI) when COVID-19 disease is suspected. Who 2020:12.

(12) Sun K, Chen J, Viboud C. Early epidemiological analysis of the coronavirus disease 2019 outbreak based on crowdsourced data: a population-level observational study. The Lancet Digital Health 2020 Apr;2(4):e201-e208. (13) Wang K, Zhang Z, Yu M, Tao Y, Xie M. 15-day mortality and associated risk factors for hospitalized patients with COVID-19 in Wuhan, China: an ambispective observational cohort study. Intensive Care Med 2020:1-3. (14) Zhou M, Zhang X, Qu J. Coronavirus disease 2019 (COVID-19): a clinical update. Frontiers of Medicine 2020;2019.

(15) Zhang J, Wang X, Jia X, Li J, Hu K, Chen G, et al. Risk factors for disease severity, unimprovement, and mortality of COVID-19 patients in Wuhan, China. Clinical Microbiology and Infection 2020.

(16) Du R, Liang L, Yang C, Wang W, Cao T, Li M, et al. Predictors of mortality for patients with COVID-19 pneumonia caused by SARS-CoV-2: a prospective cohort study. European Respiratory Journal 2020.

(17) Hu Y, Sun J, Dai Z, Deng H, Li X, Huang Q, et al. Prevalence and severity of corona virus disease 2019 (COVID-19): A systematic review and meta-analysis. Journal of Clinical Virology 2020:104371.

(18) Zhou F, Yu T, Du R, Fan G, Liu Y, Liu Z, et al. Clinical course and risk factors for mortality of adult inpatients with COVID-19 in Wuhan, China: a retrospective cohort study. The Lancet 2020;6736(20):1-9.

(19) Grasselli G, Pesenti A, Cecconi M. Critical care utilization for the COVID-19 outbreak in Lombardy, Italy: early experience and forecast during an emergency response. JAMA 2020.

(20) Docherty AB, Harrison EM, Green CA, Hardwick HE, Pius R, Norman L, et al. Features of 16,749 hospitalised UK patients with COVID-19 using the ISARIC WHO Clinical Characterisation Protocol. medRxiv 2020:2020.04.23.20076042.

(21) Bermejo-Martin JF, Almansa R, Menéndez R, Mendez R, Kelvin DJ, Torres A. Lymphopenic community acquired pneumonia as signature of severe COVID-19 infection. J Infect 2020. 
medRxiv preprint doi: https://doi.org/10.1101/2020.05.25.20112912; this version posted May 26, 2020. The copyright holder for this preprint

(which was not certified by peer review) is the author/funder, who has granted medRxiv a license to display the preprint in perpetuity. All rights reserved. No reuse allowed without permission.

(22) Wang Y, Kang H, Liu X, Tong Z. Combination of RT-qPCR testing and clinical features for diagnosis of COVID-19 facilitates management of SARS-CoV-2 outbreak. J Med Virol 2020:1-2.

(23) Huang C, Wang Y, Li X, Ren L, Zhao J, Hu Y, et al. Clinical features of patients infected with 2019 novel coronavirus in Wuhan, China. The Lancet 2020;395(10223):497-506.

(24) Huang C, Wang Y, Li X, Ren L, Zhao J, Hu Y, et al. Clinical features of patients infected with 2019 novel coronavirus in Wuhan, China. The Lancet 2020;395(10223):497-506.

(25) Xu X, Wu X, Jiang X, Xu K, Ying L, Ma C, et al. Clinical findings in a group of patients infected with the 2019 novel coronavirus (SARS-Cov-2) outside of Wuhan, China: retrospective case series. BMJ 2020;368.

(26) Yang X, Yu Y, Xu J, Shu H, Xia J, Liu H, et al. Clinical course and outcomes of critically ill patients with SARS-CoV-2 pneumonia in Wuhan, China: a single-centered, retrospective, observational study. The Lancet Respiratory Medicine 2020 May;8(5):475-481. 